a metaphysical form of his own which his early teachers would have found strange. But he never moved from their conception as to the nature and importance of the issues with which philosophy is concerned. In his hands philosophy was a way not only of thought but also of life. He had worked out his system in the grand style, compact, articulate, thorough and comprehensive, and he presented it with uncommon power.

Bowman's great work was done in the class-room and on the public platform. The tale of his publications is small : a volume of sonnets-the fruits of his prison camp experience-two or three pamphlets and a few articles in learned journals. Happily there is a bigger book almost ready for the press; and it may be hoped that in the large mass of manuscript material which he has left, enough will be found in readily publishable form to give to others than his own students, some idea of the reflections of one of the most original, interesting and courageous minds of our time.

H. J. W. Hetherington.

\section{Prof. Margaret Benson}

Prof. Margaret Benson, whose death on Saturday, June 20 , is mourned by a wide circle of friends, is known best to botanists as one of the leading palæophytologists of the last generation. Much of her early work on fossils, which began about 1904, has long been incorporated into the text-books; but it is only a year since she published her last paper on the subject. Her best work was done at a time when the technique of fossil cutting was in its infancy, and for years she cut her own sections at a small lapidary bench in a shed in the grounds of the Royal Holloway College, with a cutting machine worked by a gas engine. She left her valuable collection of fossil slides to the College.

Prof. Benson's industry and single-mindedness were quite exceptional, and were combined with a very real flair for knowing what a fossil might yield and how a structure might be interpreted. She was trained in research at Newnham College, Cambridge, and University College, London, and her early work there on the embryology of Amentiferæ, for which the D.Sc. of the University of London was conferred on her in 1894, is now a classic. In October 1893 she was appointed head of the newly founded Department of Botany at the Royal Holloway College. The Department flourished under her, and in 1912 the University conferred on her the title of University professor of botany, which chair she held at the College until her resignation in 1922 .

Prof. Benson was a great traveller and collector ; and the botanical garden, museum, herbarium and well-stocked laboratories of her College to-day bear witness to her indefatigable enthusiasm and wise foresight. In the Michaelmas term of 1897 she was granted leave of absence in order to visit the professors of botany of Brussels, Heidelberg, Tübingen, Basle, Strasbourg and Paris in their respective laboratories during term. This tour she made with the view of securing the best information for the equipment of a botanical laboratory. In later years she made two journeys to the antipodes, and on both occasions brought back quantities of valuable specimens. Her botanical work is of enduring value, and she inspired many generations of students with a love of the subject.

E. M. B.

\section{Prof. A. A. Noyes}

Tre death of Arthur Amos Noyes, director of the Gates Chemical Laboratory at the California Institute of Technology, which occurred at Pasadena on June 3 as the result of an attack of pneumonia at the age of sixty-nine years, has deprived physical chemistry of another of its pioneers of the Ostwald school. Noyes may be regarded, indeed, as the American prototype of Sir James Walker, who died last year. Just as Walker was Ostwald's first British student at Leipzig, Noyes was the first American. Of them, Ostwald remarks in his autobiography: "Both are not only distinguished as investigators and teachers, but belong also as men to the best examples of this diversified race".

For nearly twenty years the research laboratory of physical chemistry of the Massachusetts Institute of Technology, which Noyes directed and to which he personally contributed half the expenses of maintenance, was the centre of this branch of science in the United States, and many of the leading American physical chemists may be counted among his students. His own contributions to the ionic theory of electrolytes and to the principles of qualitative analysis were of primary importance in the modern development of these two fields.

Modesty and thoroughness were the chief characteristics both of Noyes' work and of his character. He sought no honours : he leaves many friends.

\section{JAMES Kendall.}

We regret to announce the following deaths :

Mr. Arthur D. Carey, known for his explorations in Central Asia, for which he was awarded the Founder's Medal of the Royal Geographical Society in 1889, on June 11, aged ninety-one years.

Prof. Ira E. Cutler, emeritus professor of zoology in the University of Denver, on May 25, aged seventythree years.

Prof. W. E. Dalby, F.R.S., emeritus professor of engineering in the City and Guilds College, Imperial College of Science and Technology, University of London, on June 26, aged seventy-two years.

Prof. Ivan Hönl, professor of bacteriology in the University of Prague, known for his work in combating the scourge of tuberculosis in Central Europe, on June 7, aged seventy years.

Mr. Frank Merricks, past-president of the Institution of Mining and Metallurgy, and a member of the Geological Survey Board in 1920-26, on June 8, aged seventy years.

Sir Charles Nathan, C.B.E., member of the Executive Council of the Australian Commonwealth Council for Scientific and Industrial Research in 1927-28, on June 5, aged seventy-six years. 